\title{
Efficacy and safety of carfilzomib in relapsed and/or refractory multiple myeloma: systematic review and meta-analysis of 14 trials
}

\author{
Chintan Shah ${ }^{1}$, Rohit Bishnoi ${ }^{1}$, Yu Wang ${ }^{2}$, Fei Zou ${ }^{2}$, Harini Bejjanki ${ }^{1}$, Samip Master ${ }^{3}$ \\ and Jan S. Moreb ${ }^{4}$ \\ ${ }^{1}$ Division of Hospital Medicine, University of Florida, Gainesville, Florida, USA \\ ${ }^{2}$ Department of Biostatistics University of Florida, Gainesville, Florida, USA \\ ${ }^{3}$ Division of Hematology/Oncology, Louisiana State University, Shreveport, Louisiana, USA \\ ${ }^{4}$ Division of Hematology/Oncology, University of Florida, Gainesville, Florida, USA \\ Correspondence to: Chintan Shah, email: cps.chintan@gmail.com; Chintan.shah@medicine.ufl.edu \\ Keywords: carfilzomib; kyprolis; multiple myeloma; response; efficacy \\ Received: January 03, $2018 \quad$ Accepted: April 06, $2018 \quad$ Published: May 04, 2018 \\ Copyright: Shah et al. This is an open-access article distributed under the terms of the Creative Commons Attribution License 3.0 \\ (CC BY 3.0), which permits unrestricted use, distribution, and reproduction in any medium, provided the original author and source \\ are credited.
}

\section{ABSTRACT}

Objective: Carfilzomib (Carf) is a second-generation proteasome inhibitor approved for patients with relapsed and/or refractory multiple myeloma (RRMM) who failed $\geq 1$ prior lines of therapy. We performed a systematic review of Carf literature with meta-analysis to determine the efficacy and safety in RRMM patients.

Methods: Based on literature search, we included a total of 14 eligible phase I/ II, phase II and phase III Carf based clinical trials. The cumulative incidence and odds ratios (OR) were calculated with random effect model, using " $R$ "' software with metaphor package.

Results: 2906 evaluable RRMM patients from published clinical trials included. The pooled overall response rate (ORR) was $45 \%$ (95\% CI: 29-62). The pooled clinical benefit rate (CBR) was 56\% (95\% CI: 41-71). OR from 3 randomized clinical trials showed that Carf significantly improved ORR and CBR compared to control groups (OR 2.4, $P<0.0001 ; 2.02, P=0.0007$, respectively). Subgroup analysis showed significantly better ORR $(P<0.0001)$ and CBR $(P<0.001)$ with combination regimens compared to monotherapy. Response was significantly higher with high dose of Carf ( $>20 / 27 \mathrm{mg} / \mathrm{m}^{2}$ ) compared to standard dose (ORR $65 \%$ vs. $35 \%, P=$ $0.03)$. Compared to control group, the OR of developing cardiotoxicity $(P=0.002)$ and hypertension $(P<0.0001)$ were significantly higher with Carf, while no difference in peripheral neuropathy $(P=0.28)$.

Conclusions: Carf produces significantly better responses with acceptable safety profile in RRMM patients. Combination regimens and higher dose Carf offers better response with no significant extra toxicity. Its efficacy is regardless of cytogenetics or disease stage. Incidences of cardiotoxicity and hypertension seem higher with Carf.

\section{INTRODUCTION}

Survival rates have improved in multiple myeloma (MM) patients since the approval of the novel therapeutics such as proteasome inhibitors (PI) and immunomodulators
(IMiDs) [1]. Bortezomib (Bort) is the first-in-class PI, which is approved in the USA for the treatment of patients with MM and mantle cell lymphoma [2]. It is modified dipeptidyl boronic acid which reversibly inhibits the protease activity of the $26 \mathrm{~S}$ proteasome responsible for 
degradation of intracellular proteins through the ubiquitinproteasome pathway [3]. Inhibition of proteasomal activity disrupts the cell signaling pathways which lead to apoptosis [4]. Carfilzomib (Carf) is the second-generation PI that irreversibly inhibits $20 \mathrm{~S}$ proteasome, and is approved as a combination therapy with dexamethasone (Dexa) or with lenalidomide (Len) plus Dexa for the treatment of patients with relapsed and/or refractory MM (RRMM) who have received one to three prior lines of therapy and as a single agent for patients with RRMM who have received one or more lines of therapy [5].

In spite of all these advances, MM still imposes a major therapeutic challenge as the majorities of the patients eventually develop resistance to these agents and relapse [6]. MM has remained incurable disease as tumor typically recurs more aggressively after each relapse and ultimately treatment-refractory disease develops and leads to the demise of patients [7]. There is no standard uniform treatment for RRMM [8]. Various randomized and nonrandomized clinical trials have used Carf either as a single agent or in various combinations with other agents, and with variable dosing schedules which have resulted in a wide range of response rates. Response rates and treatment choices depend on various disease and patient-related factors. However specific toxicity profile can impact treatment selection, especially in this group of RRMM patients as they are usually heavily pre-treated. Current standard dosing schedule of Carf is $20 \mathrm{mg} / \mathrm{m}^{2} /$ day in cycle 1 and if tolerated increase the dose in subsequent cycles to $27 \mathrm{mg} / \mathrm{m}^{2} /$ day [5]. Many clinical trials have used higher doses and slower infusion rate.

Other preclinical, as well as clinical studies suggest that Carf based combination regimens can provide synergistically superior response rates, but the impact on progression-free survival (PFS) and overall survival (OS) remains unclear [9-11]. Given all the published information about the experiences with Carf, we feel that clarification of its effectiveness as a single agent or in combination is very much needed. Here we present systematic review and meta-analysis of published clinical trials on Carf in patients with RRMM. We analyzed efficacy of Carf in RRMM patients and performed various subgroup analyses to understand effects of different doses of Carf (high vs. standard) and regimens (monotherapy vs. combination) into response rates as well as adverse events. We also performed subgroup analyses to evaluate efficacy of Carf in high risk cytogenetics and different ISS stages. Furthermore, we analyzed commonly reported adverse events including cardiotoxicity with respect to different doses of Carf.

\section{RESULTS}

Based on our search criteria, we identified a total of 14 clinical trials [12-25] which used Carf based regimens in RRMM patients with a total of 2938 enrolled patients and 2906 evaluable patients. Thirty-two patients were excluded from analysis due to various reasons such as incorrect enrollment (2), missing baseline and/ or post-baseline disease assessment (12), intolerance to maximum dose criteria of the study (12), self-withdrawal (1), reason not mentioned (5). The median age of the patients ranged between $61.5-68.5$ years. Characteristics of patients with the response and long-term outcomes from different studies are summarized in Tables 1-3. There were three randomized controlled trials (RCTs) with 2036 enrolled patients, 1017 in Carf group and 1019 in control group [16, 17, 21]. A total of 7 clinical trials used Carf in combination with other agents, such as Dexa in four studies $[12,15,16,25]$, Len and Dexa in two studies [21, 24] and panobinostat in one study [13] as shown in Tables 1-3.

\section{Response rates and survival outcomes}

The pooled overall response rate (ORR) (CR+VGPR+PR) from all 14 included studies was 45\% (95\% CI: 29-62) by random effect model. Similarly, the overall clinical benefit rate (CBR) (ORR+MR) was 56\% (95\% CI: 41-70). High heterogeneity between studies $\left(\mathrm{I}^{2} \sim 97\right)$ was observed for both. Therefore, we report separate analysis for phase III studies as compared to the rest. The pooled ORR for phase III studies was $62 \%(95 \%$ CI: 26-91) and rest of the studies was 41\% (95\% CI: $27-$ 55 ) by random effect model (Figure 1A, 1B). Similarly, the pooled CBR from phase III studies was 70\% $(95 \%$ CI: 38-93), while it was 52\% (95\% CI: 38-65) for the other phase I/II studies (Figure 1C, 1D). There was no evident publication bias found as funnel plot remained symmetrical. Table 4 shows overall proportions for complete response (CR) and very good partial response (VGPR) and their respective $\mathrm{I}^{2}$ for heterogeneity between studies.

Odds ratio (OR) calculated from 3 RCTs showed that Carf significantly improved ORR and CBR rates compared to control groups $(\mathrm{OR}=2.4,95 \% \mathrm{CI}$ : $1.6-3.4$, $P<0.0001 ; \mathrm{OR}=2.02 ; 95 \% \mathrm{CI}: 1.3-3.03, P=0.0007$, respectively). Median time to ORR ranged between $0.95-$ 3.4 months. Median PFS varied from 3.5-8.3 months in studies where Carf was used as a single agent, [17-20, 22, 23] whereas higher median PFS of 5.1-26.3 months was seen in studies in which Carf was used in combination. In the different studies, median OS in Carf groups varied from 10-47.6 months, however, OS was not usually chosen as a primary endpoint [12-25].

\section{Response rates -subgroup analyses}

As shown in Table 4, combination regimen compared to monotherapy showed significantly better response rates. A total of 5 studies used higher $(>20 / 27$ $\mathrm{mg} / \mathrm{m}^{2} /$ day) dose of Carf and 4 out of these 5 studies used 
Table 1: Patient characteristics, response and long-term outcomes summary from phase III studies with control groups

\begin{tabular}{|c|c|c|c|c|c|c|c|c|c|c|c|c|}
\hline Author, Year & $\begin{array}{l}\text { Regimen } \\
\text { used }\end{array}$ & $\begin{array}{l}\text { Carf dosing } \\
\left(\mathrm{mg} / \mathrm{m}^{2}\right)\end{array}$ & $\begin{array}{l}\text { Median } \\
\text { age } \\
\text { (years) }\end{array}$ & $\begin{array}{l}\text { Patients } \\
\text { analyzed, n }\end{array}$ & $\mathrm{CR}, n(\%)$ & $\begin{array}{l}\text { VGPR, n } \\
(\%)\end{array}$ & $\begin{array}{l}\text { ORR, } n \\
\text { (\%) }\end{array}$ & $\begin{array}{l}\text { CBR, } n \\
(\%)\end{array}$ & $\begin{array}{l}\text { Median } \\
\text { DOR } \\
\text { (mos) }\end{array}$ & $\begin{array}{l}\text { Median } \\
\text { PFS } \\
\text { (mos) }\end{array}$ & $\begin{array}{l}\text { Median } \\
\text { OS } \\
(\text { mos })\end{array}$ & $\begin{array}{l}\text { Type of cardiac } \\
\text { events }\end{array}$ \\
\hline $\begin{array}{l}\text { Dimopoulos } \\
\text { MA et al., } 2016\end{array}$ & Carf, Dexa & $\begin{array}{l}20 \text { (Days } 1,2 \text { of } \\
\text { cycle 1) f/b } 56\end{array}$ & 65 & 464 & $58(13)$ & $194(42)$ & $356(77)$ & $380(82)$ & NA & 18.7 & 47.6 & $\begin{array}{l}\text { Cardiac failure, } \\
\text { Ischemic heart }\end{array}$ \\
\hline (ENDEAVOR) & Bort, Dexa & & 65 & 465 & $29(6)$ & $104(22)$ & $290(62)$ & $343(74)$ & NA & 9.4 & 24.3 & \\
\hline \multirow{2}{*}{$\begin{array}{l}\text { Hajek R et al., } \\
2017 \\
\text { (FOCUS) }\end{array}$} & Carf & $\begin{array}{l}20 \text { (Days } 1,2 \text { of } \\
\text { cycle } 1 \text { ) f/b } 27\end{array}$ & 63 & 157 & $1(1)$ & $5(3)$ & $30(19)$ & $49(31)$ & 7.2 & 3.7 & 10.2 & Cardiac failure \\
\hline & Pred or Dexa & & 66 & 158 & $0(0)$ & $5(3)$ & $18(11)$ & $33(21)$ & 9.5 & 3.3 & 10 & \\
\hline \multirow[t]{2}{*}{$\begin{array}{l}\text { Stewart AK et } \\
\text { al., 2015 } \\
\text { (ASPIRE) }\end{array}$} & $\begin{array}{l}\text { Carf, Len, } \\
\text { Dexa }\end{array}$ & $\begin{array}{l}20 \text { (Days } 1,2 \text { of } \\
\text { cycle 1) f/b } 27\end{array}$ & 64 & 396 & $126(31.8)$ & 277 (69.9) & $\begin{array}{l}344 \\
(87.1)\end{array}$ & $359(91)$ & 28.6 & 26.3 & NA & $\begin{array}{l}\text { cardiac failure, } \\
\text { ischemic heart } \\
\text { disease }\end{array}$ \\
\hline & Len, Dexa & & 65 & 396 & $37(9.3)$ & $160(40.4)$ & $\begin{array}{l}264 \\
(66.7)\end{array}$ & $\begin{array}{l}302 \\
(76.3)\end{array}$ & 21.2 & 17.6 & NA & \\
\hline
\end{tabular}

Abbreviations: Carf, carfilzomib; CR, complete response; VGPR, very good partial response; ORR, overall response rate; CBR, clinical benefit rate; PFS, progression free survival; OS, overall survival, Pred, prednisone; Dexa, dexamethasone; Len, lenalidomide; Bort, bortezomib; NA, not available; f/b, followed by; mos, months; MI, myocardial infarction; CHF, congestive heart failure; CAD, coronary artery disease;

Table 2: Patient characteristics, response and long-term outcomes summary from phase II studies

\begin{tabular}{|c|c|c|c|c|c|c|c|c|c|c|c|c|}
\hline $\begin{array}{l}\text { Author, } \\
\text { Year }\end{array}$ & Regimen used & $\begin{array}{l}\text { Carf dosing } \\
\left(\mathrm{mg} / \mathrm{m}^{2}\right)\end{array}$ & $\begin{array}{l}\text { Median } \\
\text { age (years) }\end{array}$ & Pts analyzed, $n$ & $\begin{array}{l}\text { CR, } n \\
(\%)\end{array}$ & $\begin{array}{c}\text { VGPR, } n \\
(\%)\end{array}$ & ORR, $n(\%)$ & $\begin{array}{c}\text { CBR, } n \\
(\%)\end{array}$ & $\begin{array}{c}\text { Median DOR } \\
(\mathrm{mos})\end{array}$ & $\begin{array}{l}\text { Median PFS } \\
\quad(\mathrm{mos})\end{array}$ & $\begin{array}{c}\text { Median } \\
\text { OS } \\
\text { (mos) }\end{array}$ & $\begin{array}{l}\text { Type of } \\
\text { cardiac } \\
\text { events }\end{array}$ \\
\hline $\begin{array}{l}\text { Lendvai } \\
\text { N et al., } \\
2014\end{array}$ & Carf & $\begin{array}{l}20 \text { (Days } 1, \\
2 \text { of cycle } 1) \\
\quad \text { f/b } 56\end{array}$ & 63 & 42 & $1(2)$ & $9(21)$ & $23(55)$ & $25(60)$ & 11.7 & 4.1 & 20.3 & $\begin{array}{l}\text { Heart } \\
\text { failure }\end{array}$ \\
\hline $\begin{array}{l}\text { Siegel } \\
\text { DS et al., } \\
2012\end{array}$ & Carf & $\begin{array}{c}20 \text { (Days } 1, \\
2 \text { of cycle } 1 \text { ) } \\
\text { f/b } 27\end{array}$ & 63 & 257 & $1(0.4)$ & $13(5.1)$ & $61(23.7)$ & $95(37)$ & 7.8 & 3.7 & 15.6 & $\begin{array}{l}\text { Cardiac } \\
\text { failure, } \\
\text { cardiac } \\
\text { arrest, MI }\end{array}$ \\
\hline $\begin{array}{l}\text { Jagannath } \\
\text { S et al., } \\
2012\end{array}$ & Carf & $\begin{array}{c}20 \text { (Days } 1 \\
2,8,9,15 \\
16)\end{array}$ & 63.5 & 46 & NA & NA & $7(16.7)$ & $10(24)$ & 7.2 & 3.5 & NA & $\begin{array}{l}\text { Cardiac } \\
\text { failure }\end{array}$ \\
\hline $\begin{array}{l}\text { Wang } \\
\text { M et al., } \\
2013\end{array}$ & Carf, Len, Dexa & $\begin{array}{c}20 \text { (Days } 1, \\
2 \text { of cycle } 1 \text { ) } \\
\text { f/b } 27\end{array}$ & 61.5 & 84 & $1(1.2)$ & $30(35.7)$ & $58(69.0)$ & $64(76)$ & 18.8 & 11.8 & NA & $\begin{array}{c}\text { MI, } \\
\text { sick-sinus } \\
\text { syndrome, } \\
\text { CAD }\end{array}$ \\
\hline $\begin{array}{l}\text { Vij R et } \\
\text { al., } 2012\end{array}$ & Carf & $\begin{array}{c}20 \text { (Days 1, } \\
2 \text { of cycle } 1 \text { ) } \\
\text { f/b } 27\end{array}$ & 63 & 35 & $1(2.9)$ & $1(2.9)$ & $6(17.1)$ & $11(31.4)$ & NA & 4.6 & 29.9 & $\mathrm{CHF}$ \\
\hline $\begin{array}{l}\text { Vij R et } \\
\text { al.,2012 }\end{array}$ & Carf & $\begin{array}{l}20 \text { (Days } 1, \\
2 \text { of cycle } 1) \\
\text { f/b } 27\end{array}$ & 66 & 126 & $3(2.4)$ & $26(20.6)$ & $60(47.6)$ & $78(62)$ & NA & NA & NA & CHF \\
\hline $\begin{array}{l}\text { Badros } \\
\text { AZ et al., } \\
2013\end{array}$ & Carf, Dexa & $\begin{array}{c}15 \text { (cycle 1) } \\
\text { f/b } 20 \text { (cycle } \\
\text { 2) f/b } 27\end{array}$ & 64 & 47 & 0 & 0 & $12(25.5)$ & $15(32)$ & 7.9 & NA & NA & $\mathrm{CHF}$ \\
\hline
\end{tabular}

Abbreviations: See Table 1.

it in a combination regimen. High dose of Carf showed better CR and VGPR rates when compared to standard dose Carf but was not statistically significant $(P \geq 0.18)$. However, ORR was significantly higher with a high dose of Carf at 65\% (95\% CI: 53-76) compared to 35\% using standard dose (95\% CI: 15-59) with $P=0.03$. Similarly, high dose of Carf significantly $(P=0.01)$ improved CBR to $74 \%$ (95\% CI: $65-82$ ) over that of $38 \%$ (95\% CI: $26-$ 51) from standard dose. We found no significant difference in ORR between patients with high risk and standard risk cytogenetics treated by Carf based regimens (OR 0.84, 95\% CI: 0.59-1.18, $P=0.62$ ). Similarly, no significant $(P$ $\geq 0.32$ ) difference in ORR was found between the different ISS stages $(33 \%, 22 \%, 27 \%$, respectively for ISS stage I, II, and III).

\section{Common adverse events}

Common high-grade (grade $\geq 3$ ) hematological adverse events reported were anemia (15.3\%), thrombocytopenia $(17 \%)$, neutropenia (15\%), and lymphopenia (23\%). Similarly, cumulative incidences of high-grade non-hematological adverse events reported were pneumonia $(8 \%)$, fatigue $(6 \%)$, cardiotoxicity $(5 \%)$ (Figure 2A), HTN (5\%) (Figure 2B), renal toxicity (5\%), diarrhea $(2 \%)$, upper respiratory airways infection $(1 \%)$, pyrexia $(1 \%)$, nausea $(1 \%)$ and peripheral neuropathy (1\%). When compared to control group from 3 RCTs, we found that the odds of developing cardiotoxicity and HTN were significantly higher in Carf group with OR 2.04 (95\% CI: $1.31-3.17, P=0.002)$ and 3.33 (95\% CI: $1.98-5.60, P<0.0001$ ), respectively (Table 5). 
Table 3: Patient characteristics, response, and long-term outcomes summary from phase I/II trials

\begin{tabular}{|c|c|c|c|c|c|c|c|c|c|c|c|c|}
\hline $\begin{array}{l}\text { Author, } \\
\text { Year }\end{array}$ & $\begin{array}{c}\text { Regimen } \\
\text { used }\end{array}$ & $\begin{array}{c}\text { Carf dosing } \\
\left(\mathrm{mg} / \mathrm{m}^{2}\right)\end{array}$ & $\begin{array}{c}\text { Median age } \\
\text { (years) }\end{array}$ & $\begin{array}{c}\text { Pts } \\
\text { analyzed, } n\end{array}$ & $\begin{array}{c}\text { CR, } n \\
(\%)\end{array}$ & $\begin{array}{c}\text { VGPR, } n \\
(\%)\end{array}$ & $\begin{array}{c}\text { ORR, } n \\
(\%)\end{array}$ & CBR, $n(\%)$ & $\begin{array}{c}\text { MedianDOR } \\
(\mathrm{mos})\end{array}$ & $\begin{array}{c}\text { Median PFS } \\
(\text { mos) }\end{array}$ & $\begin{array}{c}\text { Median OS } \\
(\text { mos })\end{array}$ & $\begin{array}{c}\text { Type of cardiac } \\
\text { events }\end{array}$ \\
\hline $\begin{array}{l}\text { Watanabe } \\
\text { T et al., } \\
2016\end{array}$ & $\begin{array}{l}\text { Carf, } \\
\text { Dexa }\end{array}$ & $\begin{array}{c}20 \text { (Days } 1,2 \text { of } \\
\text { cycle } 1 \text { ) f/b } 27\end{array}$ & 67 & 50 & 0 & $2(4)$ & $10(20)$ & $14(28)$ & 9.5 & 5.1 & 23.4 & $\begin{array}{c}\text { CHF, } \\
\text { atrioventricular } \\
\text { block, } \\
\text { cardiomyopathy }\end{array}$ \\
\hline $\begin{array}{l}\text { Berenson } \\
\text { JR et al., } \\
2016\end{array}$ & $\begin{array}{l}\text { Carf, } \\
\text { Dexa }\end{array}$ & $\begin{array}{c}20 \text { (Days } 1 \text { of } \\
\text { cycle } 1 \text { ) f/b } 45 \\
\text { or } 56 \text { or } 70 \text { or } 88 \\
\text { (once weekly) }\end{array}$ & 68.5 & 104 & $11(11)$ & $34(33)$ & 77 (77) & $84(84)$ & NA & 12.6 & NA & $\begin{array}{l}\text { MI, atrial } \\
\text { fibrillation, } \\
\text { cardiorespiratory } \\
\text { arrest, CHF }\end{array}$ \\
\hline $\begin{array}{l}\text { Berdeja } \\
\text { JG et al., } \\
2015\end{array}$ & Carf, Pano & $\begin{array}{c}20 \text { (Days } 1,2 \text { of } \\
\text { cycle } 1 \text { ) } f / b 27 \text { or } \\
36 \text { or } 45^{\epsilon}\end{array}$ & 66 & 42 & NA & $14(33)$ & $28(67 \%)$ & $33(79)$ & 11.6 & 7.7 & NA & $\mathrm{CHF}$ \\
\hline $\begin{array}{l}\text { Berenson } \\
\text { JR et al., } \\
2014\end{array}$ & Carf $^{*}$ & $\begin{array}{c}20(\text { cycle } 1) \mathrm{f} / \mathrm{b} \\
27(\text { cycle } 2) \mathrm{f} / \mathrm{b} \\
36(\text { cycle } 3) \mathrm{f} / \mathrm{b} \\
45(\text { cycle } 4)^{*}\end{array}$ & 67 & 37 & $3(8.1)$ & $6(16.2)$ & $16(43.2)$ & $23(62.2)$ & 9.9 & 8.3 & 15.8 & $\begin{array}{c}\text { Tachyarrhythmia, } \\
\text { CHF }\end{array}$ \\
\hline
\end{tabular}

Abbreviations: See Table 1

\#in various combinations with immunomodulatory drug (Thal or Len), pegylated liposomal doxorubicin, glucocorticoids, cyclophosphamide, methylprednisone, bendamustine

${ }^{€} 4(9.5 \%)$ out 42 patients had maximum carfilzomib dose $\leq 27 \mathrm{mg} / \mathrm{m}^{2}$,

"10 (27\%) out 37 patients had maximum carfilzomib dose $\leq 27 \mathrm{mg} / \mathrm{m}^{2}$

\section{Common adverse events -subgroup analyses}

We performed analyses based on regimen used (monotherapy vs. combination) and a dose of Carf (high dose vs. standard dose) for all common highgrade adverse events mentioned above. Interestingly, the incidences of all commonly reported high-grade toxicities including cardiotoxicity were not significantly different between high versus standard Carf doses except for HTN (Supplementary Table 1). A trend towards a higher cumulative incidence of HTN was found at $8.7 \%$ with high dose Carf (95\% CI: 4-14.6\%) as compared to 3.06\% with standard dose (95\% CI: $0.7-6.5 \%)$. Moreover, the incidences of all commonly reported high-grade toxicities were not significantly different between combination therapy and monotherapy except for peripheral neuropathy $(1.6 \%$ vs. $0.3 \%$, respectively; $P=0.04)$ and diarrhea (3.3\% vs. $0.5 \%$, respectively; $P=0.002$ ) (Supplementary Table 1). Cumulative incidences of cardiotoxicity were not significantly different between high dose vs. standard dose

Overall response rate (Phase III only)

\section{A}

Study

Proportion $[95 \% \mathrm{Cl}]$

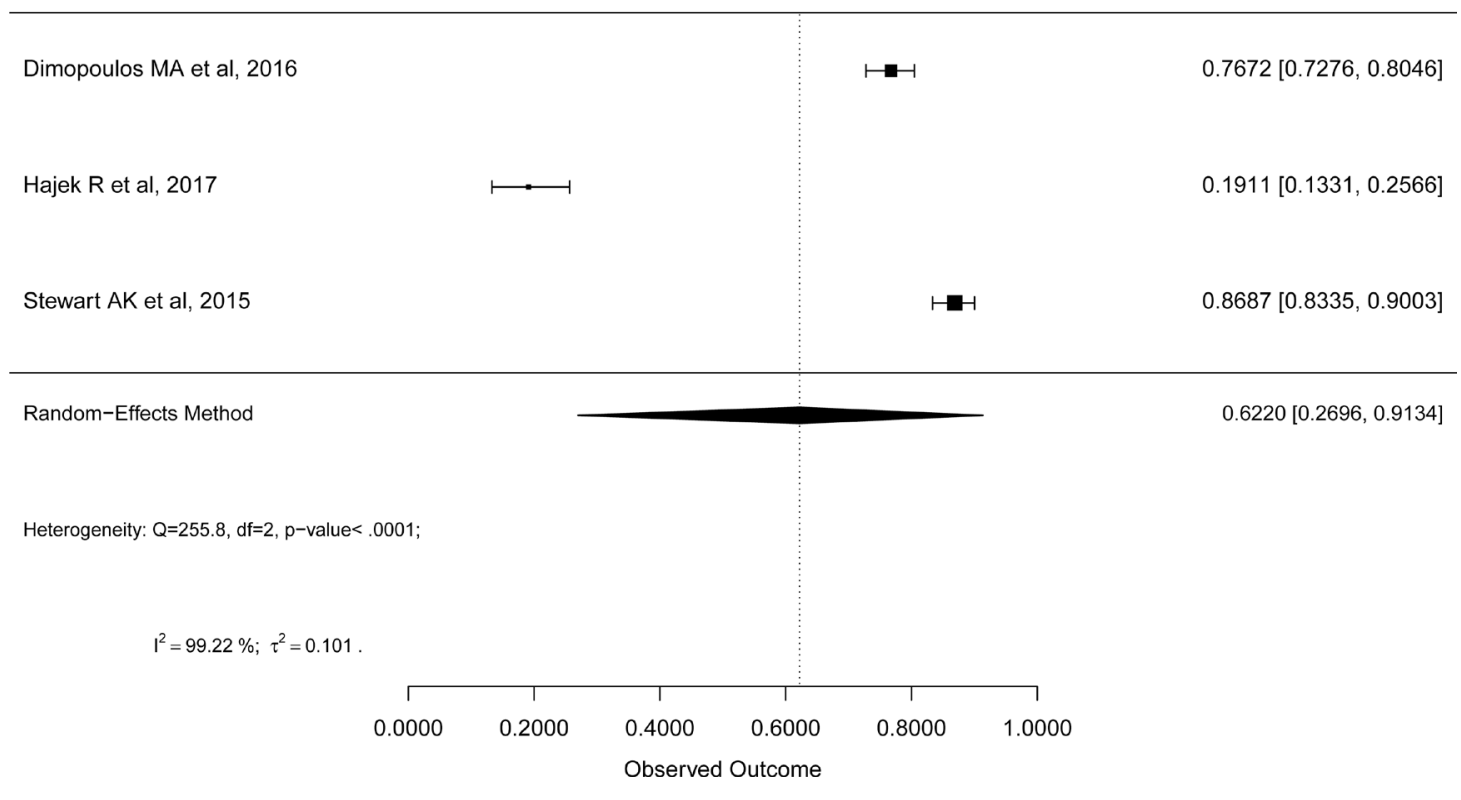




\section{B}

\section{Overall response rate (Phase III excluded)}

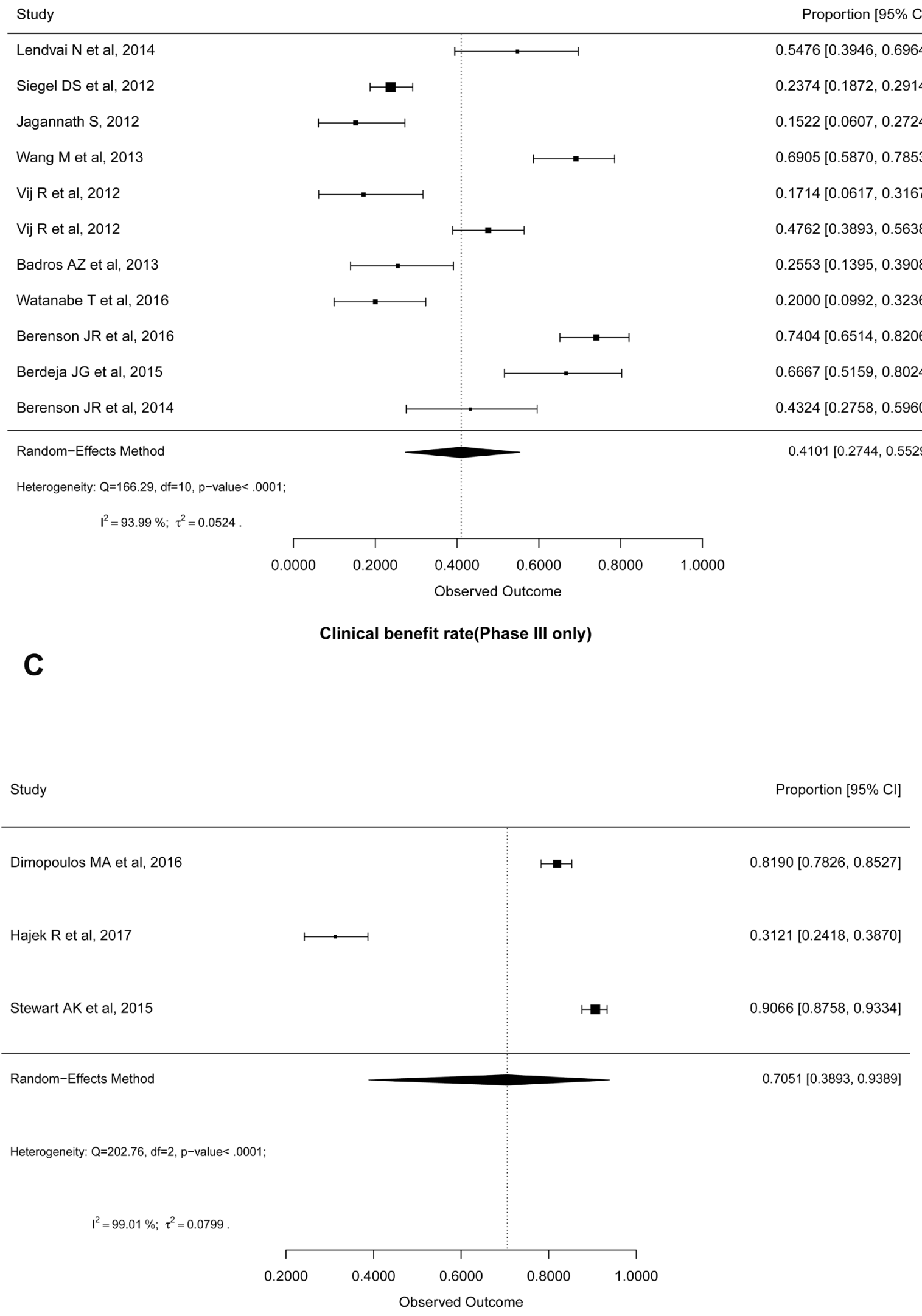


D

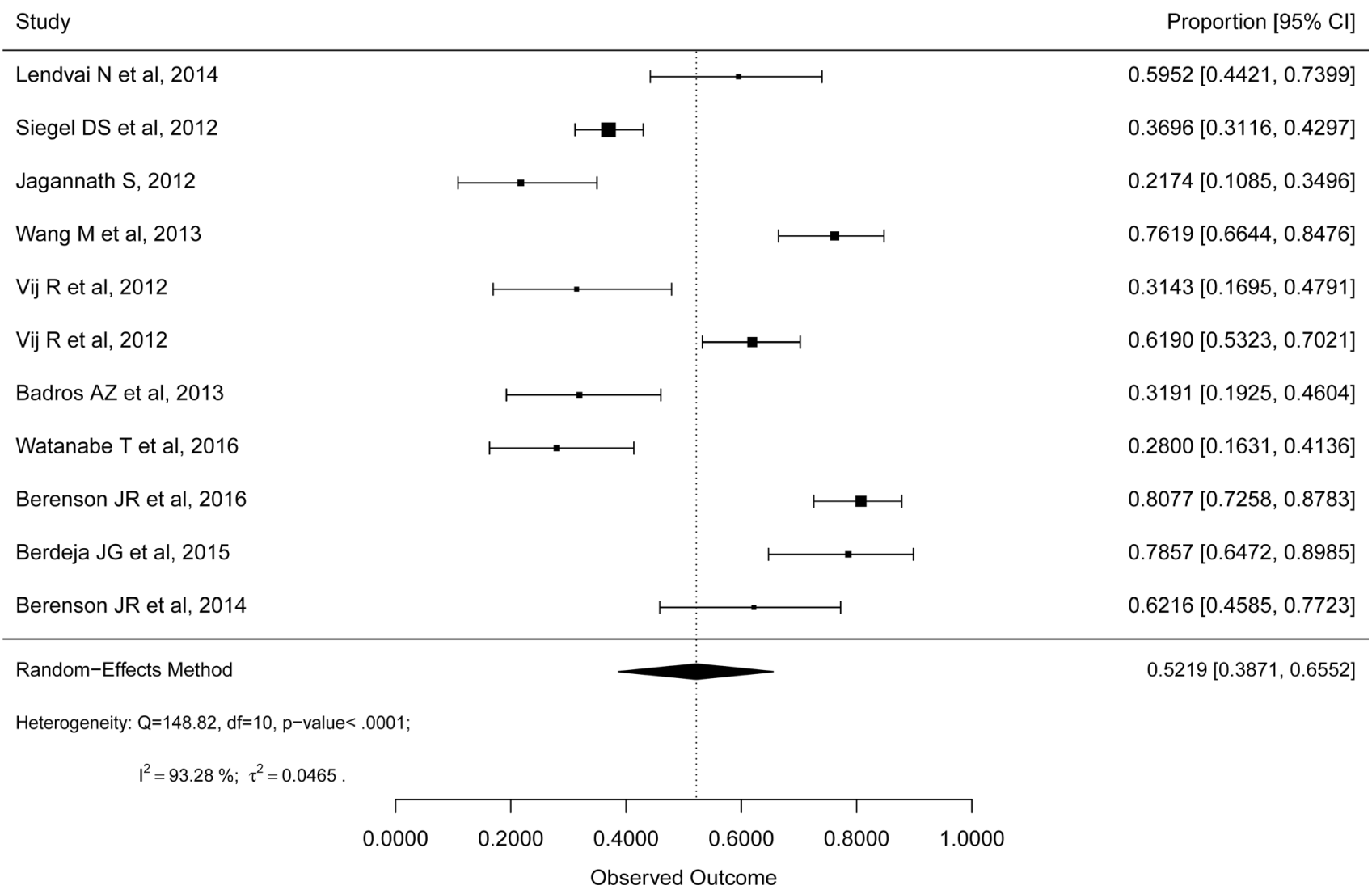

Figure 1: Forest plots of pooled response rates in Carf treated RRMM patients: (A) Overall response rate of phase III studies, (B) Overall response rate of phase II and I/II studies, (C) Clinical benefit rate of phase III studies, (D) Clinical benefit rate of phase II and I/II studies.

of Carf (5.7\% vs. $4.9 \%)$ and combination vs. monotherapy $(6.2 \%$ vs. $4 \%$ ) of Carf (Supplementary Table 1$)$.

\section{Bias}

No publication bias was detected by visual inspection of funnel plots and by Egger's tests. Study quality and risks of biases were assessed using the Cochrane Collaboration's tools. Among the RCTs, the risk of selection bias and attrition bias were low while performance bias, detection bias, and reporting bias were unclear as per Cochrane Collaboration's tools. Among non-randomized trials, the overall risks of biases were low.

\section{DISCUSSION}

To our knowledge, this is the first meta-analysis incorporating 14 clinical trials which used Carf based regimens, analyzing data on 2906 RRMM patients.

By analyzing the published data, we found the ORR and CBR to be $45 \%$ and $56 \%$, respectively, with Carf based regimens. Median PFS ranged from 3.7-18.7 months, and median OS ranged from 10.2-47.6 months [12-27]. Prognosis in MM is a highly complex issue as PFS and OS can be influenced by multiple diseases and patient-related factors. The ASPIRE and ENDEAVOR studies demonstrated significantly improved median PFS and OS $[26,27]$. On the other hand, the FOCUS study did not show the difference in the median PFS $(P$ $=0.24)$ and median OS $(P=0.41)$ for the Carf group when compared with control group [17]. Multiple factors could have played a role in this reported wide variability in response benefit; one of them could be differences in enrollment criteria such as the FOCUS study enrolled patients who had received median of 5 previous treatment lines (ENDEAVOR and ASPIRE had median of 2 previous treatment lines), more patients with ECOG status $\geq 2$ $(19 \%)$ in FOCUS trial (ENDEAVOR and ASPIRE did not have any patients with ECOG $>2$ ), single-agent Carf use in FOCUS trial, and also higher percentage of patients with PD (17\%) at the time of enrollment in the FOCUS trial. Regardless, Carf seems to offer much better OS as a median OS of 9 months is typically seen for patients who are refractory to Bort and/or IMiDs [6]. The responses to 
Table 4: Response rate analysis: overall and subgroup analysis comparing monotherapy versus combination therapy and high dose versus standard dose of Carf

\begin{tabular}{|c|c|c|c|c|c|c|c|}
\hline $\begin{array}{l}\text { Response } \\
\text { rates }\end{array}$ & Sub-group & Trials, $N$ & Total events, $N$ & $\begin{array}{c}\text { Total patients, } \\
\qquad N\end{array}$ & $\begin{array}{c}I^{2} \\
\text { statistics }\end{array}$ & $\begin{array}{c}\text { Response rates \% } \\
(95 \% \mathrm{CI})\end{array}$ & $P$-value \\
\hline \multirow[t]{7}{*}{$\overline{\mathrm{CR}}$} & Overall & 12 & 206 & 1799 & 95.79 & $4.55(0.61-11.14)$ & \\
\hline & Regimens & & & & & & \\
\hline & Monotherapy & 6 & 6 & 672 & 0 & $0.62(0.06-1.57)$ & \\
\hline & Combination & 6 & 200 & 1127 & 94.98 & $9.74(2.60-20.32)$ & 0.005 \\
\hline & Dose of Carf & & & & & & \\
\hline & High & 4 & 73 & 647 & 41.68 & $9.43(5.81-13.74)$ & \\
\hline & Standard & 8 & 133 & 1152 & 97.2 & $3.13(0.00-13.04)$ & 0.19 \\
\hline \multirow[t]{7}{*}{ VGPR } & Overall & 13 & 611 & 1841 & 98.05 & $19.17(7.44-34.50)$ & \\
\hline & Regimens & & & & & & \\
\hline & Monotherapy & 6 & 47 & 672 & 83.9 & $5.36(1.45-11.15)$ & \\
\hline & Combination & 7 & 564 & 1169 & 95.59 & $36.21(22.19-51.51)$ & $<0.0001$ \\
\hline & Dose of Carf & & & & & & \\
\hline & High & 5 & 257 & 689 & 77.67 & $30.16(21.07-40.07)$ & \\
\hline & Standard & 8 & 354 & 1152 & 98.78 & $13.83(0.70-37.68)$ & 0.18 \\
\hline \multirow[t]{7}{*}{ ORR } & Overall & 14 & 1088 & 1887 & 97.94 & $45.67(29.56-62.24)$ & \\
\hline & Regimens & & & & & & \\
\hline & Monotherapy & 7 & 186 & 718 & 83.19 & $24.10(16.24-32.91)$ & \\
\hline & Combination & 7 & 902 & 1169 & 89.97 & $69.66(59.67-78.8$ & $<0.0001$ \\
\hline & Dose of Carf & & & & & & \\
\hline & High & 5 & 500 & 689 & 83.66 & $65.05(53.22-76.05)$ & \\
\hline & Standard & 9 & 588 & 1198 & 98.42 & $35.70(15.08-59.47)$ & 0.03 \\
\hline \multirow[t]{7}{*}{ CBR } & Overall & 14 & 1240 & 1887 & 97.45 & $56.37(41.38-70.80)$ & \\
\hline & Regimens & & & & & & \\
\hline & Monotherapy & 7 & 272 & 718 & 85.47 & $35.16(25.53-45.41)$ & \\
\hline & Combination & 7 & 968 & 1169 & 86.69 & $77.92(69.85-85.07)$ & 0.001 \\
\hline & Dose of Carf & & & & & & \\
\hline & High & 5 & 545 & 689 & 74.74 & $74.71(65.75-82.76)$ & \\
\hline & Standard & 9 & 695 & 1198 & 98.08 & $38.54(26.38-51.46)$ & 0.01 \\
\hline
\end{tabular}

Abbreviations: CR, complete response; VGPR, very good partial response; ORR, overall response rate; CBR, clinical benefit rate; Carf, carfilzomib; CI, confidence interval;

Carf appeared to be durable, with median DOR ranging between 7.2-28.6 months, lower with single-agent [1723] while higher with combination therapy.

ASPIRE study excluded patients who progressed on Bort, showed the highest ORR (87\%) and CBR (91\%) to Carf. Vij et al. [22, 23] showed patients who were Bort naïve had better ORR (47\%) and CBR (61\%) compared to patients refractory to Bort \{ORR (17\%) and CBR (31\%)\}. Collectively, this information suggests that while Carf is efficacious in patients previously treated with Bort, the response rates were not as robust. The mechanism by which Carf overcomes resistance to Bort is unclear [28], but it may partially be due to the irreversible nature of proteasome inhibition with more selective inhibition by
Carf [28-30]. As shown in results, ORR $(P=0.03)$ and CBR $(P=0.01)$ were significantly better with higher dose Carf ( $>20 / 27 \mathrm{mg} / \mathrm{m}^{2} /$ day) compared to standard Carf dose, irrespective of regimen (monotherapy or combination). This is consistent with the results of preclinical studies [28-30]. Moreover, preclinical data [31] suggested that a slower infusion over a longer period (30 min infusion as opposed to $10 \mathrm{~min}$ ) compared to a rapid infusion of the same dose of Carf resulted in a better tolerance of Carf with the potential for greater and more prolonged proteasome inhibition and improved efficacy. As shown in results, while high dose of Carf offered better response rates, it was without any significantly added toxicities except for HTN $(P=0.05)$. While the most frequently used 
High grade cardiotoxicity

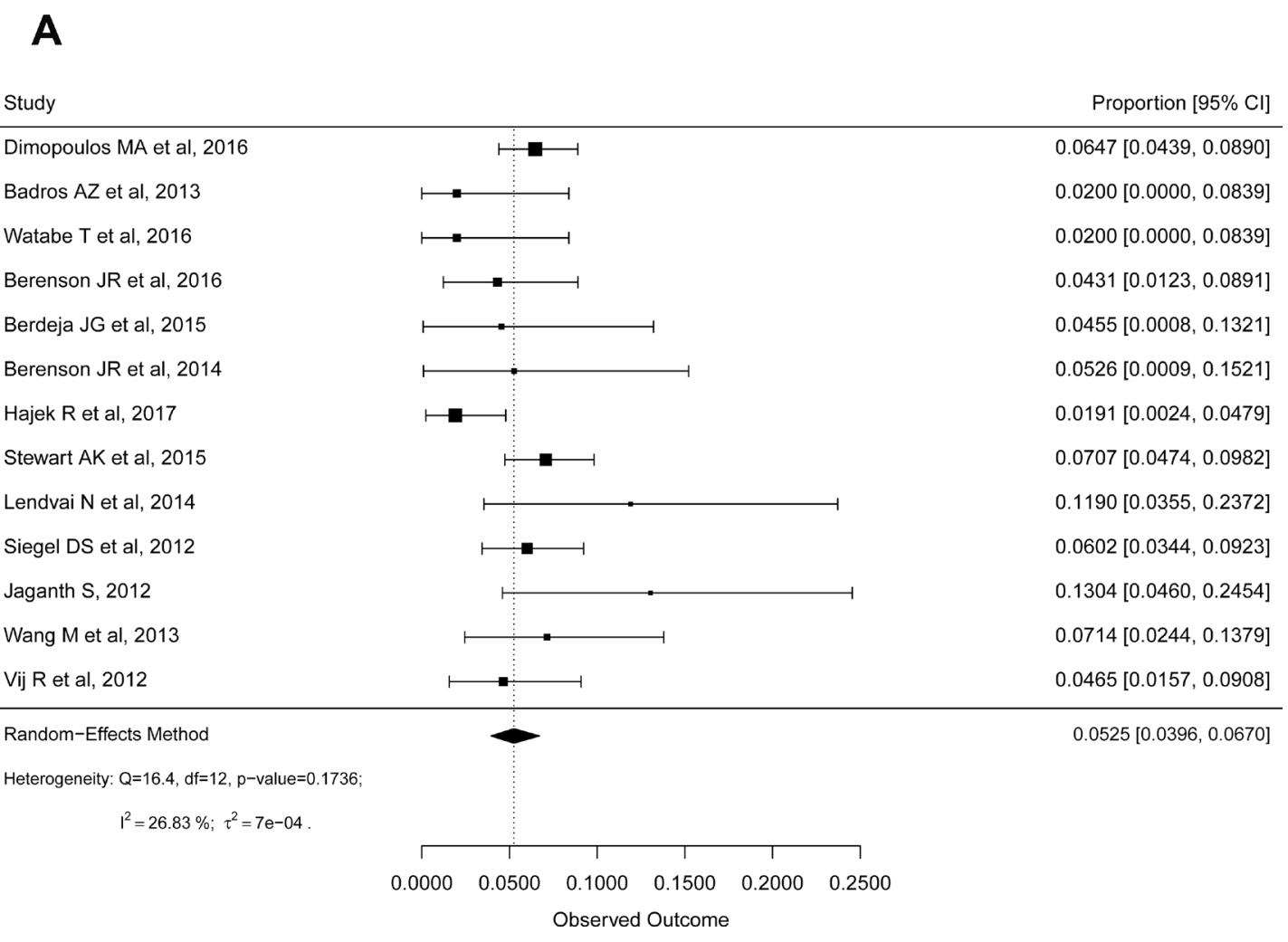

B

High grade HTN

Study

Proportion [95\% Cl]

Dimopoulos MA et al, 2016

Watabe T et al, 2016

Berenson JR et al, 2016

Berdeja JG et al, 2015

Berenson JR et al, 2014

Hajek R et al, 2017

Stewart AK et al, 2015

Lendvai $\mathrm{N}$ et al, 2014

Siegel DS et al, 2012

Vij R et al, 2012

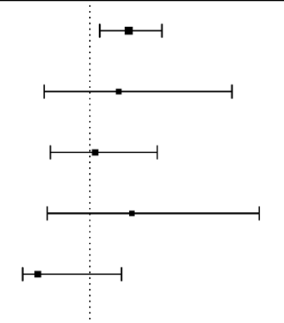

$0.0884[0.0641,0.1160]$

$0.0800[0.0178,0.1744]$

$0.0603[0.0231,0.1121]$

$0.0909[0.0204,0.1970]$

$0.0126[0.0000,0.0824]$

$0.0318[0.0090,0.0662]$

$0.0429[0.0249,0.0654]$

$0.2619[0.1385,0.4067]$

$0.0038[0.0000,0.0161]$

$0.0571[0.0010,0.1646]$

Random-Effects Method

$0.0559[0.0265,0.0940]$

Heterogeneity: $Q=58.26, d f=9, p$-value $<.0001 ;$

$I^{2}=84.55 \% ; \tau^{2}=0.0094$

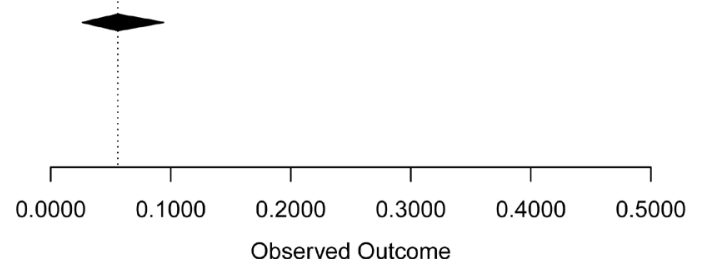

Figure 2: Forest plots of cumulative incidences of high-grade cardiotoxicity (A) and hypertension (B). 
Table 5: Odds ratio (OR) calculations for common adverse events comparing events in Carf versus control groups from phase III trials

\begin{tabular}{lcccccc}
\hline Adverse events & No. of trials & Total events, $\boldsymbol{N}$ & Total pts, $\boldsymbol{N}$ & $\mathbf{I}^{2}$ statistics & OR (95\% CI) & $P$-value \\
\hline Hematological & & & & & & \\
Anemia & 3 & 336 & 2036 & 55.78 & $1.12(0.78-1.62)$ & 0.53 \\
Thrombocytopenia & 3 & 267 & 2036 & 8.72 & $1.16(0.88-1.53)$ & 0.28 \\
Neutropenia & 2 & 250 & 1107 & 60.47 & $0.93(0.50-1.74)$ & 0.81 \\
Non-hematological & & & & & & \\
Neuropathy & 3 & 70 & 2036 & 65.46 & $0.54(0.18-1.65)$ & 0.28 \\
Renal toxicity & 3 & 90 & 2036 & 56.46 & $1.85(0.93-3.67)$ & 0.07 \\
Fatigue & 2 & 112 & 1721 & 25.82 & $0.97(0.62-1.51)$ & 0.87 \\
Diarrhea & 2 & 80 & 1721 & 51.76 & $0.64(0.33-1.27)$ & 0.20 \\
Nausea & 2 & 13 & 1244 & 0 & $1.60(0.51-4.99)$ & 0.41 \\
Upper respiratory & 2 & 23 & 1721 & 0 & $2.28(0.93-5.61)$ & 0.07 \\
infection & 28 & 2036 & 0 & $4.13(1.61-10.58)$ & 0.001 \\
Pyrexia & 3 & 28 & 315 & 0 & $0.50(0.22-1.11)$ & 0.08 \\
Pneumonia & 1 & 29 & 2036 & 0 & $2.04(1.31-3.17)$ & 0.002 \\
Cardiotoxicity & 3 & 61 & 2036 & 0 & $3.33(1.98-5.60)$ & $<0.0001$ \\
Hypertension & 3 & 64 & &
\end{tabular}

Abbreviations: OR, odds ratio; CI, confidence interval.

higher Carf dose was $56 \mathrm{mg} / \mathrm{m}^{2} /$ day, the most effective and safe higher Carf dose remains to be determined.

Most high-risk disease factors including unfavorable cytogenetics and higher ISS stages are associated with short-lived remissions, rapid relapses and aggressive disease [32]. Our analysis shows no difference in ORR between patients with standard-risk versus high-risk cytogenetics $(P=0.62)$ among those treated by Carf. Furthermore, our analysis also shows that Carf is equally efficacious for all ISS stages. These findings suggest that Carf could be used in wide spectrum of patient populations including patients with unfavorable cytogenetic abnormalities and advanced ISS stage. However, Carf does not seem to completely overcome the overall poor prognosis of high risk patients who show lower PFS and OS compared to standard risk patients [33].

Our analysis shows that the most commonly reported adverse events were hematological with no significant difference between Carf and control group. Interestingly, ORs for developing cardiotoxicity $(P=0.002)$ and HTN $(P<0.0001)$ were significantly higher with Carf [43]. Cardiotoxicity of these novel agents is thought to be the result of modulation of endothelial nitric oxide synthase (eNOS) activity and nitric oxide (NO) levels by proteasome inhibition [34]. Thus, Carf being irreversible PI would provide a prolonged inhibition which could result in sustained oxidative stress in some patients and lead to higher cardiotoxicity incidence. On the other hand, higher incidence of HTN induced by Carf was suggested to be due to an autonomic neuropathy induced by proteasome inhibition $[25,35]$. It is recommended that

patients receiving Carf be closely monitored for cardiac complications, however, proper monitoring strategy needs to be determined. Moreover, identifying predisposing factors for cardiotoxicity needs further research as traditional cardiovascular risk factors did not show any association in a retrospective analysis [36].

Our meta-analysis shows that the cumulative incidence of high-grade $(\geq 3)$ peripheral neuropathy reported in Carf trials was $1.1 \%$, which seems to be much lower than the $8.1 \%$ reported in Bort trials [37]. Indeed peripheral neuropathy is a major dose-limiting side effect with Bort treatment $[38,39]$ and published reports suggest the possibility of underlying genetic factors for the development of Bort induced peripheral neuropathy [40]. Other explanations for less neuropathy with Carf could be due to being more selective [41] and faster clearance from the circulation after intravenous administration [31]. Furthermore, studies have also found that baseline peripheral neuropathy does not impact the efficacy and tolerability of Carf [42]. All these observations point to an advantage of using Carf in patients who have already had existing neuropathy from prior exposure to Bort, knowing that it may not get worse.

As with all other meta-analyses, ours has a few limitations: 1) This analysis was based on the published data of clinical trials, whereas an individual level databased analysis would have more detailed information on patient variables; 2) Patients enrolled in trials usually have adequate organ function and are relatively healthier compared to the patients in common oncology practice; 3 ) The reporting of cardiotoxicity was highly variable among 
different studies, [14-16, 21, 25] where some studies reported it in a broad category as "cardiac failure", while others used more specific terminology such as congestive heart failure, arrhythmias, atrioventricular block, cardiomyopathy or cardiac arrest. Dyspnea was used as the pulmonary adverse event in earlier studies, although it is likely resulting from pulmonary congestion caused by congestive heart failure [20, 25]; 4) Marked heterogeneity between studies. We chose the random-effects model for all calculations to increase power and precision; 5) Majority of studies which used a high dose of Carf, used variable doses and due to lack of individual patient level data, we were not able to perform analysis to see which higher dose, in particular, is most effective and safest.

In conclusion, our analysis shows treatment with Carf based regimens offers significantly better response rates and survival rates with an acceptable safety profile in patients with RRMM. Combination regimens compared to single-agent Carf and high versus standard dose seem to offer better response rates with an acceptable toxicity profile. Moreover, Carf seems to be efficacious irrespective of the cytogenetics and ISS stage. The cumulative incidences of cardiotoxicity and HTN are higher in patients treated with Carf and the odds of developing HTN increases with the use of higher Carf dose. Finally, the incidence of peripheral neuropathy, unlike with Bort, does not seem to be an issue with Carf.

\section{MATERIALS AND METHODS}

The selection and systematic review of trials were performed in accordance with the Preferred Reporting Items for Systematic Reviews and Meta-Analysis (PRISMA) statement [44].

\section{Literature search strategy}

Two investigators ( $\mathrm{CS}$ and $\mathrm{RB}$ ) conducted an independent literature search of PubMed, Web of Science, and clinical trial registry (http://clinicaltrials. gov). We also searched abstracts from American Society of Clinical Oncology and American Society of Hematology conferences that took place up until January 2017. Key words used were carfilzomib, Kyprolis, PR171 , and cancer. Reference list of selected studies and other published systematic reviews were also searched separately to capture any relevant studies. Studies with full article published prior to January 2017 were selected. In the case of multiple publications originating from a single trial or duplicate publications, only the most recent and updated report of the clinical trial was included.

\section{Inclusion and exclusion criteria}

All the studies enrolled patients who relapsed after receiving $\geq 1$ previous lines of therapy which usually included Bort, Len and/or Thal. Vij et al. [23] enrolled and studied Bort naïve patients separately. ASPIRE study excluded patients who progressed during treatment with Bort [21]. Berenson et al. enrolled only those patients who relapsed within 12 weeks of receiving or were refractory to their most recent Bort-containing regimen [15].

\section{Selection of studies and data extraction}

The primary goal of the meta-analysis was to analyze response rates of Carf in RRMM patients and carry out sub-group analyses. Secondary goals were to analyze common adverse events reported in trials as well as perform analyses to assess the effects of reported disease variables on responses and outcomes. We included only prospective trials published prior to January 2017 and written in the English language. Studies were included if the participants were assigned to treatment with Carf as a single agent or in combination with other agents. We excluded a total of 32 phase I studies as our primary goal is to analyze efficacy of Carf. Complete step by step selection process of clinical trials is described in Figure 3.

Two investigators ( $\mathrm{CS}$ and $\mathrm{RB}$ ) independently conducted the data extraction from 14 included studies, and any discrepancy between the two was resolved by consensus. These data include first author's name, year of publication, phase of clinical trials, underlying malignancy and histology, disease stage and disease characteristics, inclusion and exclusion criteria, total number of enrolled patients and controls, the median age of patients, dose of Carf, treatment regimen, response categories as per International Myeloma Working Group Uniform response criteria [45] such as CR,VGPR, partial response (PR), ORR, stable disease (SD), progressive disease (PD), and common adverse events. Furthermore, minimal response (MR) and CBR were also gathered as mentioned in the respective studies as per European Blood and Marrow Transplantation Group criteria [46]. When reported, we also gathered the following data: PFS, OS, the median duration of treatment, median time to overall response, the median duration of overall response. As for the adverse events, studies recorded the adverse events as all-grade or high-grade based on the Common Terminology Criteria for Adverse Events (CTCAE) version 2, 3, or 4, which is widely accepted in clinical trials [47]. Adverse events were not included in calculations whenever it was specifically reported in the article that the events were not secondary to the drug of interest. Adverse cardiac events reported were: acute coronary syndrome, acute left or right ventricular failure, acute myocardial infarction, angina pectoris, various arrhythmias, cardiac arrest, cardiac failure and cardiomyopathy. Details of reported cardiac events from individual studies are mentioned in Tables 1, 2, and 3.

\section{Subgroup analyses}

First, in order to analyze the difference in the response rates and adverse event rates based on the dose of 
Carf used, we divided studies into two groups: studies that used standard dose $\left(\leq 27 \mathrm{mg} / \mathrm{m}^{2}\right)$ and those used high dose (such as $36,45,56,70,88 \mathrm{mg} / \mathrm{m}^{2}$ ). In a second analysis, we calculated the response rates and adverse event rates based on the regimen used, such as Carf monotherapy versus combination with other agents. Furthermore, we also analyzed the effect of high risk cytogenetics [such as $\mathrm{t}(4 ; 14), \mathrm{t}(14 ; 16)$, or deletion $17 \mathrm{p}]$ and disease status based on ISS stage on the response rates and outcomes of patients treated with Carf based regimens.

\section{Study quality and statistical analysis}

Study quality and risk of bias was assessed using the Cochrane Collaboration's tools [48]. The pooled cumulative incidences of toxicities and its 95\% confidence intervals (CI) were derived by random-effects model (DerSimonianLaird estimator) based on the reported number of patients with events of interest among evaluable patients that received Carf in respective studies. From studies with control groups, pooled OR and its $95 \%$ CIs were also

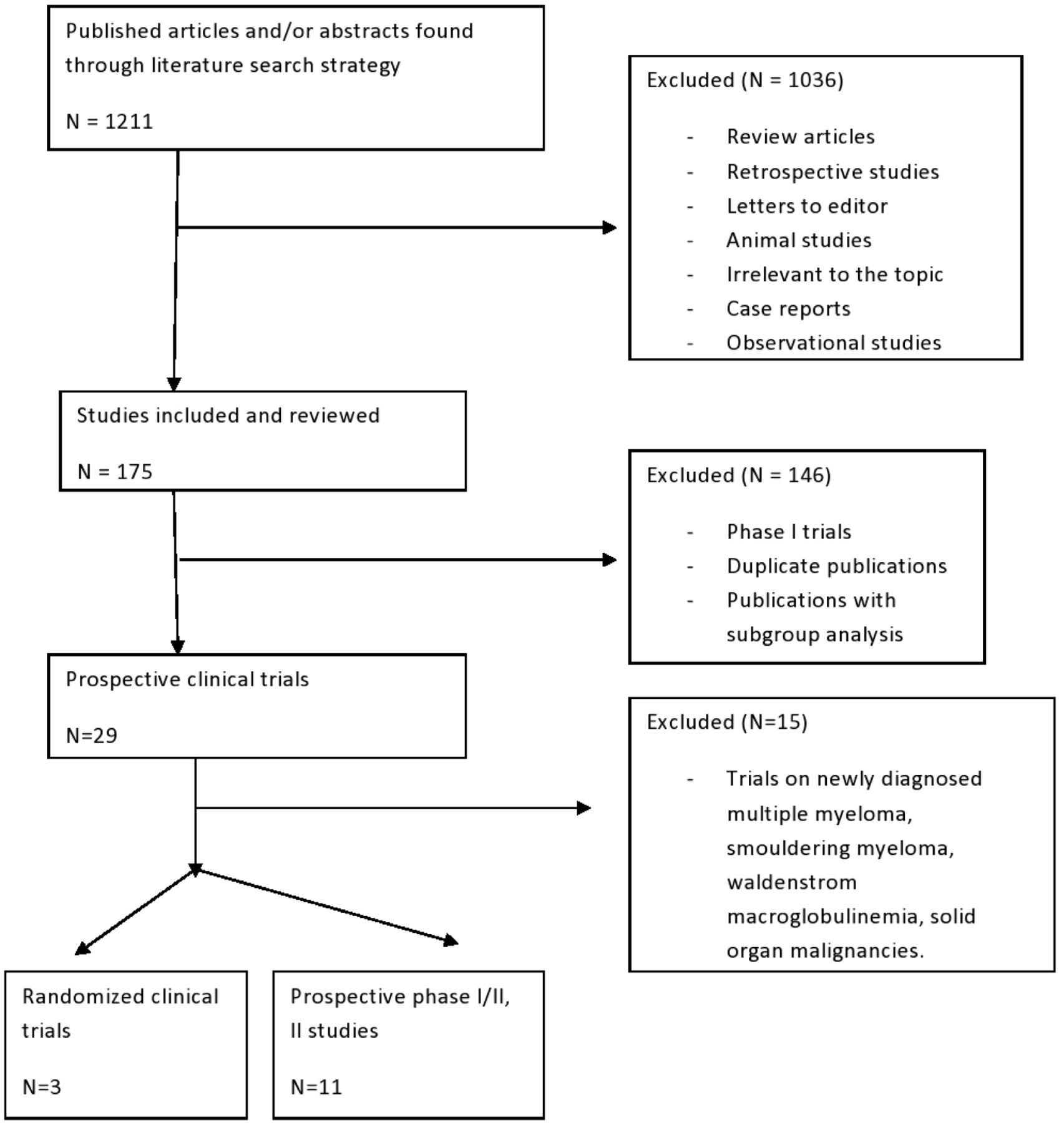

Figure 3: Schema of step by step process for selection of studies included in this meta-analysis. 
calculated by random-effects model (DerSimonian-Laird estimator). In subgroup analyses, Satterthwaite $T$-test was applied to compare the two proportions. All tests with $P$-value $<0.05$ were considered statistically significant. The heterogeneity between studies was assessed by I-squared $\left(\mathrm{I}^{2}\right)$ statistic, where values $<25 \%, 25-50 \%$ and $>50 \%$ were considered as a low, moderate and high degree of heterogeneity, respectively [49]. The publication bias was assessed by visual inspection of the funnel plots and Egger's tests [50]. All statistics were calculated using " $\mathrm{R}$ " software with metafor package [51].

\section{Abbreviations}

MM: Multiple myeloma; PI: Proteasome inhibitor; IMiDs: Immunomodulators; Bort: Bortezomib; Carf: Carfilzomib; Dexa: Dexamethason; Len: Lenalidomide; RRMM: relapsed and/or refractory multiple myeloma; DOR: Duration of response; PFS: Progression free survival; OS: overall survival; CR: Complete response; VGPR: Very good partial response; PD: progressive disease; MR: Minimal response; ORR: Overall response rate; $\mathrm{CBR}$ : Clinical benefit rate; SD: Stable disease; ISS: International staging system; OR: Odds ratio; HTN: Hypertension.

\section{Author contributions}

$\mathrm{CS}$ and RB performed the protocol design, literature search, data extraction, quality assessment, and drafted the manuscript. HB and SM assisted in data extraction, quality assessment, and drafted the manuscript. YW and FZ contributed in statistical analysis and quality assessment. JM guided the entire work and critically revised the manuscript. All authors contributed in reviewing and revising the manuscript.

\section{CONFLICTS OF INTEREST}

None.

\section{FUNDING}

None.

\section{REFERENCES}

1. Libby E, Garcia D, Quintana D, Fekrazad MH, Bauman J, Ebaid A, Hromas R, Rabinowitz I, Wiggins C. Diseasespecific survival for patients with multiple myeloma: significant improvements over time in all age groups. Leuk Lymphoma. 2014; 55:2850-57. https://doi.org/10.3109/104 28194.2014.897700.

2. Velcade label-accessdata FDA. 2008. Available from https://www.accessdata.fda.gov/drugsatfda_docs/ label/2008/021602s015lbl.pdf.
3. Groll M, Berkers CR, Ploegh HL, Ovaa H. Crystal structure of the boronic acid-based proteasome inhibitor bortezomib in complex with the yeast $20 \mathrm{~S}$ proteasome. Structure. 2006; 14:451-56. https://doi.org/10.1016/j.str.2005.11.019.

4. Hasinoff BB, Patel D, Wu X. Molecular Mechanisms of the Cardiotoxicity of the Proteasomal-Targeted Drugs Bortezomib and Carfilzomib. Cardiovasc Toxicol. 2017; 17:237-50. https://doi.org/10.1007/s12012-016-9378-7.

5. Kyprolis label-accessdata FDA. 2015. Available from https://www.accessdata.fda.gov/drugsatfda_docs/ label/2015/202714s009lbl.pdf

6. Kumar SK, Rajkumar SV, Dispenzieri A, Lacy MQ, Hayman SR, Buadi FK, Zeldenrust SR, Dingli D, Russell SJ, Lust JA, Greipp PR, Kyle RA, Gertz MA. Improved survival in multiple myeloma and the impact of novel therapies. Blood. 2008; 111:2516-20. https://doi. org/10.1182/blood-2007-10-116129.

7. Kumar SK, Lee JH, Lahuerta JJ, Morgan G, Richardson PG, Crowley J, Haessler J, Feather J, Hoering A, Moreau P, LeLeu X, Hulin C, Klein SK, et al, and International Myeloma Working Group. Risk of progression and survival in multiple myeloma relapsing after therapy with IMiDs and bortezomib: a multicenter international myeloma working group study. Leukemia. 2012; 26:149-57. https://doi. org/10.1038/leu.2011.196.

8. Kumar SK, Callander NS, Alsina M, Atanackovic D, Biermann JS, Chandler JC, Costello C, Faiman M, Fung HC, Gasparetto C, Godby K, Hofmeister C, Holmberg L, et al. Multiple Myeloma, Version 3.2017, NCCN Clinical Practice Guidelines in Oncology. J Natl Compr Canc Netw. 2017; 15:230-69. https://doi.org/10.6004/jnccn.2017.0023.

9. Muchtar E, Gatt ME, Rouvio O, Ganzel C, Chubar E, Suriu C, Tadmor T, Shevetz O, Lavi N, Shochat T, Cohen YC, Avivi I, Raanani P, Magen H. Efficacy and safety of salvage therapy using Carfilzomib for relapsed or refractory multiple myeloma patients: a multicentre retrospective observational study. Br J Haematol. 2016; 172:89-96. https://doi.org/10.1111/bjh.13799.

10. Chauhan D, Anderson KC. Mechanisms of cell death and survival in multiple myeloma (MM): therapeutic implications. Apoptosis. 2003; 8:337-43. https://doi. org/10.1023/A:1024164700094.

11. Chauhan D, Hideshima T, Anderson KC. Apoptotic signaling in multiple myeloma: therapeutic implications. Int J Hematol. 2003; 78:114-20. https://doi.org/10.1007/ BF02983378.

12. Badros AZ, Vij R, Martin T, Zonder JA, Kunkel L, Wang Z, Lee S, Wong AF, Niesvizky R. Carfilzomib in multiple myeloma patients with renal impairment: pharmacokinetics and safety. Leukemia. 2013; 27:1707-14. https://doi. org/10.1038/leu.2013.29.

13. Berdeja JG, Hart LL, Mace JR, Arrowsmith ER, Essell JH, Owera RS, Hainsworth JD, Flinn IW. Phase I/II study of the combination of panobinostat and carfilzomib in patients with relapsed/refractory multiple myeloma. 
Haematologica. 2015; 100:670-76. https://doi.org/10.3324/ haematol.2014.119735.

14. Berenson JR, Hilger JD, Yellin O, Dichmann R, PatelDonnelly D, Boccia RV, Bessudo A, Stampleman L, Gravenor D, Eshaghian S, Nassir Y, Swift RA, Vescio RA. Replacement of bortezomib with carfilzomib for multiple myeloma patients progressing from bortezomib combination therapy. Leukemia. 2014; 28:1529-36. https:// doi.org/10.1038/leu.2014.27.

15. Berenson JR, Cartmell A, Bessudo A, Lyons RM, Harb W, Tzachanis D, Agajanian R, Boccia R, Coleman M, Moss RA, Rifkin RM, Patel P, Dixon S, et al. CHAMPION-1: a phase $1 / 2$ study of once-weekly carfilzomib and dexamethasone for relapsed or refractory multiple myeloma. Blood. 2016; 127:3360-68. https://doi.org/10.1182/ blood-2015-11-683854.

16. Dimopoulos MA, Moreau P, Palumbo A, Joshua D, Pour L, Hájek R, Facon T, Ludwig H, Oriol A, Goldschmidt H, Rosiñol L, Straub J, Suvorov A, et al, and ENDEAVOR Investigators. Carfilzomib and dexamethasone versus bortezomib and dexamethasone for patients with relapsed or refractory multiple myeloma (ENDEAVOR): a randomised, phase 3, open-label, multicentre study. Lancet Oncol. 2016; 17:27-38. https://doi.org/10.1016/S1470-2045(15)00464-7.

17. Hájek R, Masszi T, Petrucci MT, Palumbo A, Rosiñol L, Nagler A, Yong KL, Oriol A, Minarik J, Pour L, Dimopoulos MA, Maisnar V, Rossi D, et al. A randomized phase III study of carfilzomib vs low-dose corticosteroids with optional cyclophosphamide in relapsed and refractory multiple myeloma (FOCUS). Leukemia. 2017; 31:107-14. https://doi.org/10.1038/leu.2016.176.

18. Jagannath S, Vij R, Stewart AK, Trudel S, Jakubowiak AJ, Reiman T, Somlo G, Bahlis N, Lonial S, Kunkel LA, Wong A, Orlowski RZ, Siegel DS. An open-label single-arm pilot phase II study (PX-171-003-A0) of low-dose, singleagent carfilzomib in patients with relapsed and refractory multiple myeloma. Clin Lymphoma Myeloma Leuk. 2012; 12:310-18. https://doi.org/10.1016/j.clml.2012.08.003.

19. Lendvai N, Hilden P, Devlin S, Landau H, Hassoun H, Lesokhin AM, Tsakos I, Redling K, Koehne G, Chung DJ, Schaffer WL, Giralt SA. A phase 2 single-center study of carfilzomib $56 \mathrm{mg} / \mathrm{m} 2$ with or without low-dose dexamethasone in relapsed multiple myeloma. Blood. 2014; 124:899-906. https://doi.org/10.1182/blood-2014-02-556308.

20. Siegel D, Martin T, Wang M, Vij R, Jakubowiak A, Lonial S, Trudel S, Kukreti V, Bahlis N, Alsina M, Chanan-Khan A, Buadi F, Reu F, et al. A phase 11 study (PX-171-003-A1) of single-agent carfilzomib in patients with advanced relapsed and refractory multiple myeloma. Onkologie. 2013; 36:38-39.

21. Stewart AK, Rajkumar SV, Dimopoulos MA, Masszi T, Špička I, Oriol A, Hájek R, Rosiñol L, Siegel DS, Mihaylov GG, Goranova-Marinova V, Rajnics P, Suvorov A, et al, and ASPIRE Investigators. Carfilzomib, lenalidomide, and dexamethasone for relapsed multiple myeloma. N Engl J Med. 2015; 372:142-52. https:/doi. org/10.1056/NEJMoa1411321.

22. Vij R, Siegel DS, Jagannath S, Jakubowiak AJ, Stewart AK, McDonagh K, Bahlis N, Belch A, Kunkel LA, Wear S, Wong AF, Wang M. An open-label, single-arm, phase 2 study of single-agent carfilzomib in patients with relapsed and/ or refractory multiple myeloma who have been previously treated with bortezomib. Br J Haematol. 2012; 158:739-48. https://doi.org/10.1111/j.1365-2141.2012.09232.x.

23. Vij R, Wang M, Kaufman JL, Lonial S, Jakubowiak AJ, Stewart AK, Kukreti V, Jagannath S, McDonagh KT, Alsina M, Bahlis NJ, Reu FJ, Gabrail NY, et al. An open-label, single-arm, phase 2 (PX-171-004) study of single-agent carfilzomib in bortezomib-naive patients with relapsed and/or refractory multiple myeloma. Blood. 2012; 119:5661-70. https://doi.org/10.1182/ blood-2012-03-414359.

24. Wang M, Martin T, Bensinger W, Alsina M, Siegel DS, Kavalerchik E, Huang M, Orlowski RZ, Niesvizky R. Phase 2 dose-expansion study (PX-171-006) of carfilzomib, lenalidomide, and low-dose dexamethasone in relapsed or progressive multiple myeloma. Blood. 2013; 122:3122-28. https://doi.org/10.1182/blood-2013-07-511170.

25. Watanabe $T$, Tobinai $K$, Matsumoto M, Suzuki K, Sunami K, Ishida T, Ando K, Chou T, Ozaki S, Taniwaki M, Uike N, Shibayama H, Hatake K, et al. A phase 1/2 study of carfilzomib in Japanese patients with relapsed and/ or refractory multiple myeloma. Br J Haematol. 2016; 172:745-56. https://doi.org/10.1111/bjh.13900.

26. Dimopoulos MA, Goldschmidt H, Niesvizky R, Joshua D, Chng WJ, Oriol A, Orlowski RZ, Ludwig H, Facon T, Hajek R, Weisel K, Hungria V, Minuk L, et al. Carfilzomib or bortezomib in relapsed or refractory multiple myeloma (ENDEAVOR): an interim overall survival analysis of an open-label, randomised, phase 3 trial. Lancet Oncol. 2017; 18:1327-37. https://doi.org/10.1016/S1470-2045(17)30578-8.

27. Siegel DS, Dimopoulos MA, Ludwig H, Facon T, Goldschmidt H, Jakubowiak A, San-Miguel J, Obreja M, Blaedel J, Stewart AK. Improvement in Overall Survival With Carfilzomib, Lenalidomide, and Dexamethasone in Patients With Relapsed or Refractory Multiple Myeloma. J Clin Oncol. 2018; 36:728-34; Epub ahead of print. https:// doi.org/10.1200/JCO.2017.76.5032.

28. Kuhn DJ, Chen Q, Voorhees PM, Strader JS, Shenk KD, Sun CM, Demo SD, Bennett MK, van Leeuwen FW, Chanan-Khan AA, Orlowski RZ. Potent activity of carfilzomib, a novel, irreversible inhibitor of the ubiquitinproteasome pathway, against preclinical models of multiple myeloma. Blood. 2007; 110:3281-90. https://doi. org/10.1182/blood-2007-01-065888.

29. Groll M, Koguchi Y, Huber R, Kohno J. Crystal structure of the $20 \mathrm{~S}$ proteasome:TMC-95A complex: a non-covalent proteasome inhibitor. J Mol Biol. 2001; 311:543-48. https:// doi.org/10.1006/jmbi.2001.4869. 
30. Demo SD, Kirk CJ, Aujay MA, Buchholz TJ, Dajee M, Ho MN, Jiang J, Laidig GJ, Lewis ER, Parlati F, Shenk KD, Smyth MS, Sun CM, et al. Antitumor activity of PR-171, a novel irreversible inhibitor of the proteasome. Cancer Res. 2007; 67:6383-91. https://doi.org/10.1158/0008-5472. CAN-06-4086.

31. Yang J, Wang Z, Fang Y, Jiang J, Zhao F, Wong H, Bennett MK, Molineaux CJ, Kirk CJ. Pharmacokinetics, pharmacodynamics, metabolism, distribution, and excretion of carfilzomib in rats. Drug Metab Dispos. 2011; 39:187382. https://doi.org/10.1124/dmd.111.039164.

32. Kyle RA, Rajkumar SV. Criteria for diagnosis, staging, risk stratification and response assessment of multiple myeloma. Leukemia. 2009; 23:3-9. https://doi.org/10.1038/leu.2008.291.

33. Avet-Loiseau H, Fonseca R, Siegel D, Dimopoulos MA, Špička I, Masszi T, Hájek R, Rosiñol L, Goranova-Marinova V, Mihaylov G, Maisnar V, Mateos MV, Wang M, et al. Carfilzomib significantly improves the progression-free survival of high-risk patients in multiple myeloma. Blood. 2016; 128:1174-80. https://doi.org/10.1182/blood-2016-03-707596.

34. Wei Q, Xia Y. Proteasome inhibition down-regulates endothelial nitric-oxide synthase phosphorylation and function. J Biol Chem. 2006; 281:21652-59. https://doi. org/10.1074/jbc.M602105200.

35. Giannoccaro MP, Donadio V, Gomis Pèrez C, Borsini W, Di Stasi V, Liguori R. Somatic and autonomic small fiber neuropathy induced by bortezomib therapy: an immunofluorescence study. Neurol Sci. 2011; 32:361-63. https://doi.org/10.1007/s10072-010-0475-2.

36. Shah C, Gong Y, Szady A, Sun Q, Pepine CJ, Langaee T, Lucas AR, Moreb JS. Unanticipated Cardiotoxicity Associated with Targeted Anticancer Therapy in Patients with Hematologic Malignancies Patients: Natural History and Risk Factors. Cardiovasc Toxicol. 2018; 18:184-91.

37. Peng L, Ye X, Zhou Y, Zhang J, Zhao Q. Meta-analysis of incidence and risk of peripheral neuropathy associated with intravenous bortezomib. Support Care Cancer. 2015; 23:2813-24. https://doi.org/10.1007/s00520-015-2648-2.

38. Knopf KB, Duh MS, Lafeuille MH, Gravel J, Lefebvre P, Niculescu L, Ba-Mancini A, Ma E, Shi H, Comenzo RL. Meta-analysis of the efficacy and safety of bortezomib re-treatment in patients with multiple myeloma. Clin Lymphoma Myeloma Leuk. 2014; 14:380-88. https://doi. org/10.1016/j.clml.2014.03.005.

39. Mohty B, El-Cheikh J, Yakoub-Agha I, Moreau P, Harousseau JL, Mohty M. Peripheral neuropathy and new treatments for multiple myeloma: background and practical recommendations. Haematologica. 2010; 95:311-19. https://doi.org/10.3324/haematol.2009.012674.

40. Corthals SL, Kuiper R, Johnson DC, Sonneveld P, Hajek R, van der Holt B, Magrangeas F, Goldschmidt H, Morgan GJ, Avet-Loiseau H. Genetic factors underlying the risk of bortezomib induced peripheral neuropathy in multiple myeloma patients. Haematologica. 2011; 96:1728-32. https://doi.org/10.3324/haematol.2011.041434.
41. Arastu-Kapur S, Anderl JL, Kraus M, Parlati F, Shenk KD, Lee SJ, Muchamuel T, Bennett MK, Driessen C, Ball AJ, Kirk CJ. Nonproteasomal targets of the proteasome inhibitors bortezomib and carfilzomib: a link to clinical adverse events. Clin Cancer Res. 2011; 17:2734-43. https:// doi.org/10.1158/1078-0432.CCR-10-1950.

42. Martin T, Singhal SB, Vij R, Wang M, Stewart AK, Jagganath S, Lonial S, Jakubowiak AJ, Kukreti V, Bahlis NJ, Alsina M, Chanan-Khan AA, Somlo G, et al. Baseline peripheral neuropathy does not impact the efficacy and tolerability of the novel proteasome inhibitor carfilzomib (CFZ): results of a subset analysis of a phase 2 trial In patients with relapsed and refractory multiple myeloma (R/R MM). Blood. 2010; 116:A3031.

43. Shah C, Bishnoi R, Jain A, Bejjanki H, Xiong S, Wang Y, Zou F, Moreb JS. Cardiotoxicity associated with carfilzomib: systematic review and meta-analysis. Leuk Lymphoma. 2018 Feb 21:1-13. [Epub ahead of print]. https://doi.org/10.1080/10428194.2018.1437269.

44. Moher D, Liberati A, Tetzlaff J, Altman DG, and PRISMA Group. Preferred reporting items for systematic reviews and meta-analyses: the PRISMA statement. Int J Surg. 2010; 8:336-41. https://doi.org/10.1016/j.ijsu.2010.02.007.

45. Durie BG, Harousseau JL, Miguel JS, Bladé J, Barlogie B, Anderson K, Gertz M, Dimopoulos M, Westin J, Sonneveld P, Ludwig H, Gahrton G, Beksac M, et al, and International Myeloma Working Group. International uniform response criteria for multiple myeloma. Leukemia. 2006; 20:1467-73. https://doi.org/10.1038/sj.leu.2404284.

46. Bladé J, Samson D, Reece D, Apperley J, Björkstrand B, Gahrton G, Gertz M, Giralt S, Jagannath S, Vesole D, and Myeloma Subcommittee of the EBMT. European Group for Blood and Marrow Transplant. Criteria for evaluating disease response and progression in patients with multiple myeloma treated by high-dose therapy and haemopoietic stem cell transplantation. Br J Haematol. 1998; 102:111523. https://doi.org/10.1046/j.1365-2141.1998.00930.x.

47. Common Terminology Criteria for Adverse Events criteria V4.0 (CTCAE). Available from https://evs.nci.nih.gov/ ftp1/CTCAE/CTCAE_4.03/CTCAE_4.03_2010-06-14_ QuickReference_5x7.pdf.

48. Higgins JP, Green S, eds. Cochrane Handbook for Systematic Reviews of Interventions Version 5.1.0 [updated March 2011]. The Cochrane Collaboration. 2011. Available from http://handbook.cochrane.org.

49. Higgins JP, Thompson SG, Deeks JJ, Altman DG. Measuring inconsistency in meta-analyses. BMJ. 2003; 327:557-60. https://doi.org/10.1136/bmj.327.7414.557.

50. Egger M, Davey Smith G, Schneider M, Minder C. Bias in meta-analysis detected by a simple, graphical test. BMJ. 1997; 315:629-34. https://doi.org/10.1136/bmj.315.7109.629.

51. Viechtbauer W. Conducting meta-analyses in $\mathrm{R}$ with the metaphor package. J Stat Softw. 2010; 36:1-48. https://doi. org/10.18637/jss.v036.i03. 